Journal of Agriculture, Food and Environment (JAFE)

Journal Homepage: http://journal.safebd.org/index.php/jafe

http://doi.org/10.47440/JAFE.2021.2214

\title{
Mini Review \\ Rise in Single-Use Plastic Pollution Amid COVID-19 Pandemic: Bangladesh
Perspective
}

\author{
M. A. Ali ${ }^{*}$, A. M. Bhuiyan ${ }^{2}$, T. K. Gayen ${ }^{2}$ \\ ${ }^{1}$ Department of Agricultural Chemistry, Bangladesh Agricultural University, Mymensingh 2202, Bangladesh \\ ${ }^{2}$ Department of Chemistry, National University, Gazipur 1704, Bangladesh
}

\section{Article History \\ Received: 3 June 2021 \\ Revised: 24 June 2021 \\ Accepted: 27 June 2021 \\ Published online: 30 June 2021 \\ *Corresponding Author \\ M. A. Ali, E-mail: amdadali1@gmail.com}

\author{
Keywords \\ Plastic Pollution, Microplastics, \\ Biodiversity, Pandemic, Waste \\ Management, SARS-CoV-2
}

\section{A B S T R A C T}

This paper describes the surge in single-use plastic use, waste generation and related consequences amid the pandemic in Bangladesh. 14,500 tons of dangerous plastic waste was collected in the very first month of official lockdown in Bangladesh, which was almost twice that of collected before pandemic ( 7250 tons per month). COVID-19 related medical waste in Bangladesh is haphazardly thrown away, much of which carries the coronavirus. Individual choices during lockdowns are also increasing plastic demand. Packaged take-out meals and home delivered groceries contributed $40 \%$ of plastic waste. Crucially, the virus can remain active on plastic surfaces for two to three days. However, it only infectious for up to 24 hours on cardboard or paper. From these findings it can be extrapolated that paper bags could be a better alternative for plastic bags, not only due to the short lifetime of the virus but also because paper bags are more environmentally friendly. Finally, we made some recommendations on how to reduce the use of single-use plastic, and recent status of biodegradable plastic items manufacturing industries in Bangladesh.

(C) 2021 The Authors. Published by Society of Agriculture, Food and Environment (SAFE). This is an Open Access article distributed under the terms of the Creative Commons Attribution 4.0 License (http://creativecommons.org/licenses/by/4.0)

\section{Introduction}

As lockdowns took place to slow the spread of coronavirus disease (SARS-CoV-2 or COVID-19), a surge in single-use plastic items has been observed across the globe. According to The Economist, single-use plastic consumption in USA has increased more than $250 \%$ after the beginning of COVID-19 (The Economist, 2020). Here in Bangladesh, the use of polythene and plastic shopping bags at the community level has been increasing at an unprecedented rate. In the very first month of official stay-at-home order approximately 14,500 tons of dangerous plastic waste was collected (ESDO, 2020a; The Daily Star, 2020). Polythene shopping bags were identified as the largest source of single-use plastic waste accounting for 5796 tons (ESDO, 2020a).

In addition to daily single-use plastic, there has been a dramatic increase in the use of disposable personal protective equipment (PPE) among the general people, health care workers, and service workers. In China, the production of single-use face masks soared to 116 million per day in February, approximately 12 times the usual quantity (South China Morning Post, 2020). According to United Nations, the global disposable mask market was estimated to increase from USD 800 million in 2019 to USD 166 billion in 2020 (UNCTAD, 2020).

Plastic pollution has quadrupled over the past four decades across the globe (CNN, 2019; Geyer et al., 2017). According to the United Nations, $79 \%$ of the world's plastics are discarded in landfills or are simply abandoned to nature, with only 9\% recycled and 12\% incinerated (MEAWW, 2020). The possibility of plastic recycling may decrease further as oil prices decrease, coupled with the high cost of recycling (Zambrano-Monserrate et al., 2020). A study published in journal "Nature Climate Change" has showed that plastic will correspond to $15 \%$ of greenhouse gas emissions by 2050 if current trends continue, by comparison, all of the world's forms of transportation now account for $15 \%$ of emissions (Zheng and Suh, 2019). With a high volume of COVID-19 wastes generated within a short period of time, the segregation and treatment of waste often becomes impossible before sending it to landfill or to incineration. It is stated by United Nations Conference on Trade and Development (UNCTAD) that around $75 \%$ of coronavirus plastic will become waste, clogging our landfills and floating in our seas (UNCTAD, 2020). 


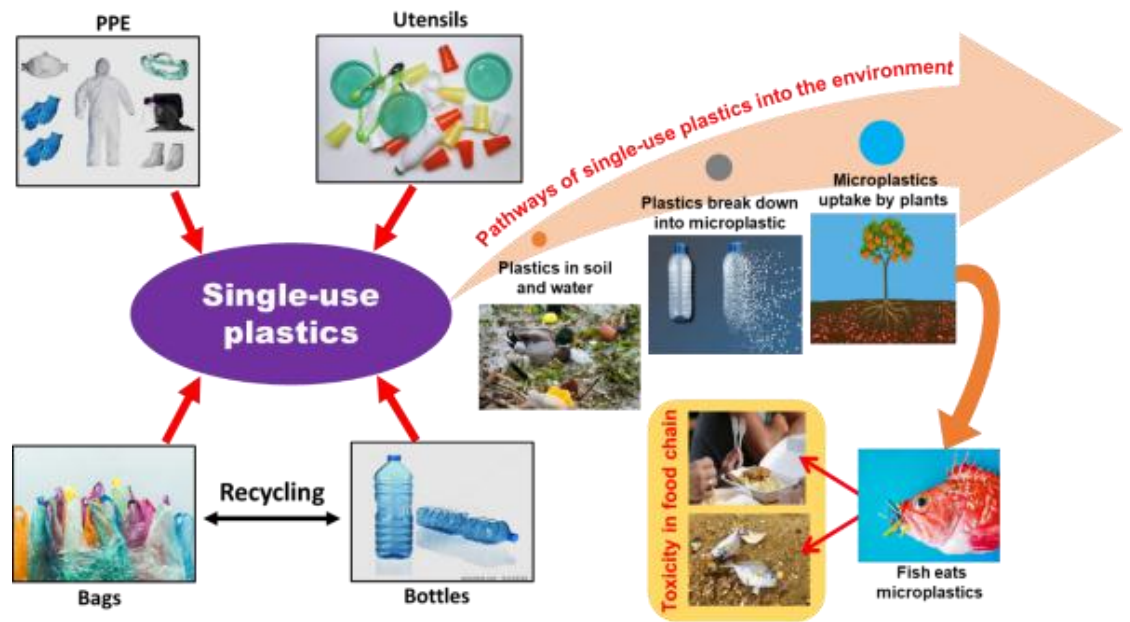

Scheme 1. Single-use plastic items during COVID-19 and transport pathways of single-use plastic pollutants in the soil, water, and surrounding environments.

Over time, single-use plastics degrade, lose their mechanical integrity, and become smaller plastic fragments and eventually microplastics (Scheme 1). This plastic debris poses a significant threat to marine species. Greenpeace reported that more than 267 different species are affected from entanglement or ingestion of marine debris. Various whale species have also been found dead after plastic ingestion (SLOACTIVE, 2020; TRIPLE PUNDIT, 2018). The growth of plants are also severely affected by uptake of microplastics through root penetration (Li et al., 2020). These plastics are not digestible by these organisms, eventually ending up in our food through consumption of affected fish and plants (Scheme 1). Furthermore, single-use plastics often contain toxic chemicals, such as bisphenols and phthalates, that are harmful for human health. For example, bisphenols cause various diseases in the human body such as prostate gland cancer, breast cancer, ovarian chromosomal damage, infertility, and type-2 diabetes (Halden, 2010).

Table 1. Polymers used to produce single-use plastic items

\begin{tabular}{|c|c|c|}
\hline Polymer & $\begin{array}{c}\text { Percentage } \\
(\%)\end{array}$ & Single-use items \\
\hline $\begin{array}{l}\text { Polyethylene } \\
\text { terephthalate (PET) }\end{array}$ & 11.04 & $\begin{array}{l}\text { Drinking bottle, container, } \\
\text { serving tray }\end{array}$ \\
\hline Polystyrene (PS) & 11.36 & Cutlery, cup, glass, plate \\
\hline $\begin{array}{l}\text { High-density } \\
\text { polyethylene } \\
\text { (HDPE) }\end{array}$ & 19.36 & $\begin{array}{l}\text { Milk bottle, freezer bag, } \\
\text { shampoo bottle, ice cream } \\
\text { container }\end{array}$ \\
\hline $\begin{array}{l}\text { Low-density } \\
\text { polyethylene } \\
\text { (LDPE) }\end{array}$ & 28 & $\begin{array}{l}\begin{array}{l}\text { Polyethylene } \\
\text { packaging, }\end{array} \\
\text { plastic }\end{array}$ \\
\hline Polypropylene (PP) & 30.24 & $\begin{array}{l}\text { Microwave box, syringe, } \\
\text { glove, stripping paper, } \\
\text { bottle cap }\end{array}$ \\
\hline
\end{tabular}

\section{Production and Waste of Single-Use Plastic}

The use of single-use plastics has been increasing every year owing to their user friendliness, low cost, light weight, and chemical resistance. Commonly used single-use plastic items in our everyday life include polyethylene bags, drinking bottle, food packaging, wrapper, cutlery, sachets, bottle caps, straws, and stirrers (UNEP, 2018). Figure 1 shows the distribution of plastic worldwide in 2018 (Statista, 2019). Of the total plastic, $60 \%$ are used to produce single-use plastic items. Table 1 shows various polymers used to produce single-use plastic items.

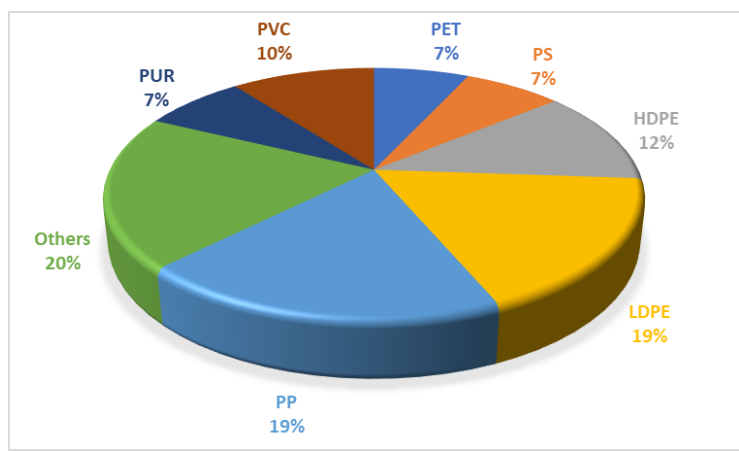

Figure 1. Distribution of different type of plastic consumption worldwide in 2018 (Statista, 2019).

In 2019, Bangladesh generated about 87,000 tons $(\sim 7250$ tons per month) of single-use plastic waste (ESDO, 2020b). The single-use plastic waste generation in Bangladesh is shown in Figure 2. The generation of single-use plastic waste has been increasing by $15 \%$ each year. The major portion of single-use plastics wastes $(>96 \%)$ is from food and personal packaging (food wrappers and sachets) (ESDO, 2020b). Of these, $33 \%$ of the plastic wastes are non-recyclable sachets. The rest of the wastes are from restaurants, airlines, residential hotels, and straws.

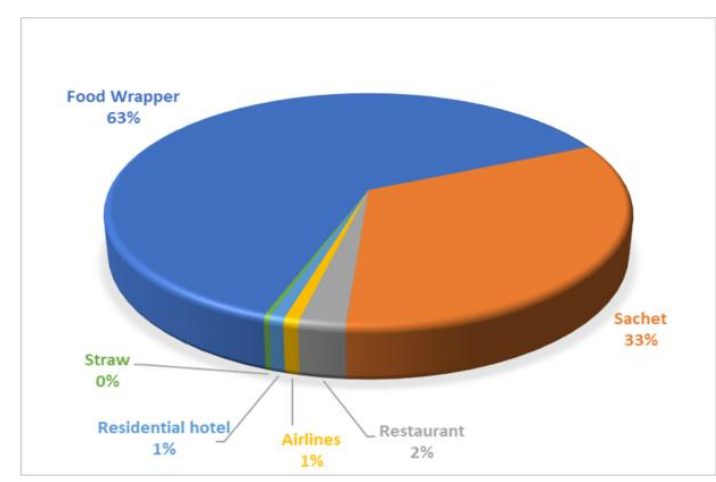

Figure 2. Single-use plastic waste generation scenario in Bangladesh before pandemic. 
After the outbreak of coronavirus, we observed a surge in the daily use of single-use plastic items at a community level in Bangladesh. 14,500 tons of dangerous plastic waste was collected in the first month of official stay-at-home conditions (ESDO, 2020a). Figure 3 shows the single-use plastic waste generation a month from March 26, 2020 to April 26, 2020. It was reported that polythene shopping bags were the largest source of single-use plastic waste, accounting for $40 \%$ of plastic waste (ESDO, 2020a). This is likely due to polythene bags being used for relief distribution and takeaway food packaging purposes. It was estimated that more than 443 tons of polythene shopping bag waste was produced in a month during relief distribution among the poor people (ESDO, 2020a).

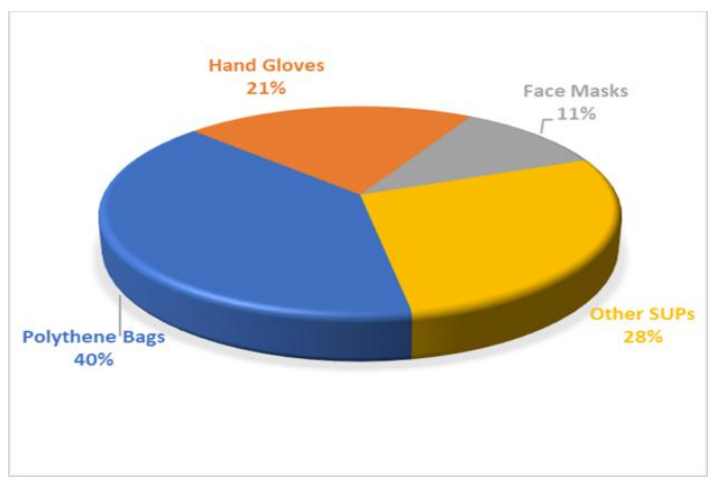

Figure 3. Single-use plastic waste generation scenario in Bangladesh in the first month of lockdown.

The use of disposable gloves has also increased significantly, both in urban and rural areas of Bangladesh. Two common types of gloves can be seen - polythene gloves and latex surgical gloves. Polythene single-use gloves are mainly used by city dwellers and street vendors, with 1216 million polythene gloves and 455 million surgical masks accounting for $33 \%$ of plastic waste (ESDO, 2020a).

Table 2. PPE commodities distributed by government of Bangladesh in the hospitals for the COVID-19 treatment (Shammi and Tareq, 2020).

\begin{tabular}{lll}
\hline PPE commodities & $\begin{array}{c}\text { Quantity used } \\
\text { (June 09, 2020) }\end{array}$ & $\begin{array}{c}\text { Quantity used } \\
\text { (August 08, 2020) }\end{array}$ \\
\hline $\begin{array}{l}\text { Apron and gown } \\
\text { Gloves for } \\
\text { examination }\end{array}$ & 76,540 & 76,653 \\
Gloves surgical & 317,901 & 506,431 \\
Hand/face/eye & 569,482 & \\
shields & 992,770 & 618,026 \\
Masks & & $1,201,127$ \\
PPE kit & $2,524,863$ & \\
Sanitizer & $1,432,206$ & $6,787,300$ \\
Shoe protector & 185,417 & $1,104,674$ \\
Others & 87,414 & 189,232 \\
\hline
\end{tabular}

In addition to the daily single-use plastics, there has been a drastic increase in other PPE, such as facemasks, face shields, aprons, shoe covers, head covers, and goggles. The material used to make PPE is non-woven polypropylene. The low-cost polymer is also used to produce potato chip bags, microwave dishes, ice cream tubs and bottle caps. The hospitals in Bangladesh produced 250 tons of single-use plastic waste in August 2020, with an additional 1.1 tons single-use plastic waste was produced by pathology laboratories which were dedicated to COVID-19 sample testing (ESDO, 2020a). The government of Bangladesh has been supplying various PPE commodities to government hospitals (Table 2). Subsequently, it is expected that as the number of patients increases, the requirement of PPE kits, masks, and gloves also increases, which in turn will increase the generation of medical and personal PPE waste. On average approximately 250 tons of COVID-19 waste are being produced per day in the capital city Dhaka alone (The Business Standard, 2020).

Several studies have also been conducted to test the survival of viruses on plastic, cardboard and paper, and fabrics. Table 3 shows the SARS-CoV-2 survival times on various surfaces. The virus can remain active on plastic surfaces for two to three days (Table 3) (Hale and Song, 2020; WebMD, 2020). However, it only infectious for up to 24 hours on cardboard or paper (WebMD, 2020). From these findings it can be extrapolated that paper bags could be a better alternative for plastic bags, not only due to the short lifetime of the virus but also because paper bags are more environmentally friendly.

Table 3. SARS-CoV-2 lifetime on various surfaces (WebMD, 2020).

\begin{tabular}{ll}
\hline \multicolumn{1}{c}{ Different surfaces } & \multicolumn{1}{c}{ Life span of virus } \\
\hline $\begin{array}{l}\text { Plastics } \\
\text { Examples: milk containers } \\
\text { and detergent bottles, } \\
\text { subway and bus seats, } \\
\text { backpacks, elevator } \\
\text { buttons }\end{array}$ & 2 to 3 days \\
$\begin{array}{l}\text { Cardboard } \\
\text { Examples: shipping boxes }\end{array}$ & 24 hours \\
$\begin{array}{l}\text { Paper } \\
\text { Examples: mail, } \\
\text { newspaper }\end{array}$ & $\begin{array}{l}\text { The length of time varies. Some } \\
\text { strains of coronavirus live for only } \\
\text { a few minutes on paper, while } \\
\text { others live for up to 5 days. } \\
\text { There is not enough research about } \\
\text { how long the virus lives on fabric, } \\
\text { Examples: clothes, linens } \\
\text { hout it is probably not as long as on } \\
\text { hard surfaces. }\end{array}$ \\
\hline
\end{tabular}

\section{Waste Management in Bangladesh}

As SARS-CoV-2 can survive on plastic surfaces for several days, it is crucial to ensure proper PPE waste management. Unfortunately, there is an absence of good incineration facilities in Bangladesh. Hence, PPE waste from the hospitals and residential areas remains a tremendous challenge. At this moment, the waste generated in hospitals is first gathered in in-house storage; from there the PPE along with other medical wastes are collected in open drums and transported to landfill areas for final disposal. However, open air collection and transportation of medical wastes over such a long distance are undoubtedly dangerous for public health (Shammi and Tareq, 2020). Unfortunately, in many rural, urban, and semi-urban hospitals, these disposal facilities are absent. These hospitals and clinics burn medical wastes outside or mix them with garbage in the regular city corporation bins.

In residential areas, the used PPE, masks, gloves, and other COVID-19 wastes were discarded among the household bins, putting the waste collectors' health and lives at risk as this infectious waste is often not labelled. Moreover, the unplanned environmental disposal of medical waste can risk the biodiversity of the riverine ecosystems of Bangladesh and may also hamper the marine ecosystem of the Bay of Bengal, as the virus can live up to 120 hours in water (Dhaka 
Tribune, 2020; The Guardian, 2020). As the PPE, disposable masks and latex gloves are all plastic polymers, these will contribute to microplastic pollution and irreversibly damage the health of these marine ecosystems.

\section{Single-Use Plastic Alternative}

According to the United Nations, 79\% of the world's plastics are discarded in landfills or are simply abandoned to the nature, around $9 \%$ are recycled and about $12 \%$ are incinerated (MEAWW, 2020). Only a small portion of single-use plastic is recycled due to the low cost of petroleum oil (raw materials for single-use plastic production) and complicated recycling process.

Manufacturers and suppliers have to consider the recycling aspect at the product design stage and ensure end-of-life products are easier to disassemble and recycle. Consumers have to use recycled plastics wherever possible and they have to avoid mixing plastics in products. We can avoid single-use plastics usage if we are careful about the dangerous effect of plastics. There are many ways to avoid single-use plastics during the COVID-19 crisis. The following are a few recommendations:

- Use a reusable bottle or mug for water and beverages

- Avoid disposable plastic hand gloves, opting for sturdy reusable PVC or neoprene glvoes

- Pick reusable or biodegradable grocery bags (sugh as bags made from Jute)

- Reuse containers for storing

- Avoid using plasticware and utensils at home

- Pack food in reusable containers or bags

Finally, the government should encourage the manufacture and use of biodegradable plastic items. Appropriate waste management can make biodegradable plastic waste into a resource. To develop a greener future, many companies are working towards sustainable biodegradable plastics. Recently, a few companies that manufacture biodegradable plastic bags have been established in Bangladesh. Table 4 is a list of the companies producing biodegradable plastic items in Bangladesh.

Table 4. Companies producing biodegradable plastic items in Bangladesh.

\begin{tabular}{|c|c|c|}
\hline Name of the company & Biodegradable plastic items & Remarks \\
\hline $\begin{array}{l}\text { Trims Sourcing (Trims } \\
\text { Sourcing, 2020) }\end{array}$ & Garments, accessories, and biodegradable plastic bags & $\begin{array}{l}\text { Fully landfill products and will not harm } \\
\text { our planet }\end{array}$ \\
\hline $\begin{array}{l}\text { Expo Accessories Ltd (Expo } \\
\text { Accessories Ltd, 2020) }\end{array}$ & $\begin{array}{l}\text { Garment accessories solutions, such as garment bags, M- } \\
\text { clip, C-clip, organic label, garment polybags, satin/ tear } \\
\text { label, hanger, woven label etc. and FSC certified paper } \\
\text { items like hang tag, virgin paper, recycled paper etc. }\end{array}$ & $100 \%$ biodegradable \& compostable \\
\hline $\begin{array}{l}\text { Captains Group (Captains } \\
\text { Group, 2020) }\end{array}$ & $\begin{array}{l}\text { Bio plastics raw material and single-use shopping bag, } \\
\text { plate, mug, box etc. }\end{array}$ & High quality and safe bioplastics \\
\hline $\begin{array}{l}\text { Ecospear Pvt. Company Ltd } \\
(\text { ECOSPEAR, 2020) }\end{array}$ & $\begin{array}{l}\text { The bag is completely made of starch and oil derived from } \\
\text { vegetables }\end{array}$ & $\begin{array}{l}\text { Their products degrade in water or soil } \\
\text { within } 90 \text { to } 180 \text { days }\end{array}$ \\
\hline
\end{tabular}

\section{Conclusion}

In this work, the current single-use plastic use, generation, and possible management options of single-use waste throughout the pandemic period have been discussed. In the context of the current pandemic situation in Bangladesh, the relevant authorities should investigate surrogate options (i.e. industrial furnaces, brick kilns) that will mitigate the spreading of COVID-19 associated with the hazardous waste. The government should also encourage the production and use of biodegradable single-use plastic and recycling facilities for protection against the secondary impacts upon health and the environment.

\section{Acknowledgement}

Authors thank to Dr. Jake A. McEwan for constructive criticism of the manuscript.

\section{Conflict of Interest}

The authors did not receive any support from any organization for this work. The authors have no conflicts of interest to declare that are relevant to the content of this article.

\section{References}

Captains Group. https://captainsgroup.com.bd/c/bio-plasticin-bangladesh (November 26, 2020).

CNN (2019). The amount of plastic in the ocean is a lot worse than we thought, Study says. https://edition.cnn.com/2019/04/16/health/ocean-plasticstudy-scn/index.html (November 26, 2020).
Dhaka Tribune (2020). World environment day: Medical waste prolonging Covid-19, threatening biodiversity. https://www.dhakatribune.com/bangladesh/environment/ 2020/06/04/world-environment-day-friday-medicalwaste-prolonging-covid-19-and-threatening-biodiversity (November 26, 2020).

Ecospear Pvt. Company Ltd. https://ecospearbd.com/ (November 26, 2020).

ESDO (2020a). ESDO's online press briefing on COVID-19 pandemic outbreak: 14,500 tons of hazardous plastic waste in a month. https://esdo.org/esdos-online-pressbriefing-on-hazardous-plastic-waste-generation-in-amonth-during-covid-19-pandemic/ (November 26, 2020).

ESDO (2020b). Single use plastic: Hidden costs of health \& environment in Bangladesh. https://esdo.org/single-useplastic-hidden-costs-of-health-environment-inbangladesh/ (November 26, 2020).

Expo Accessories Ltd. https://www.expoaccessories.com/ (November 26, 2020).

Geyer R, Jenna RJ, Law KL (2017). Production, use, and fate of all plastics ever made. Sci. Adv. 3(7): 1-5.

Halden RU (2010). Plastics and health risks. Annu. Rev. Public Health 31(1): 179-94.

Hale RC, Song B (2020). Single-use plastics and COVID-19: Scientific evidence and environmental regulations. Environ. Sci. Technol. 54(12): 7034-36.

Li L, Luo Y, Li R, Zhou Q, Peijnenburg WJGM, Yin N, Yang J, Tu C, Zhang Y (2020). Effective uptake of submicrometre plastics by crop plants via a crack-entry mode. Nat. Sustain. 3(11): 929-937. 
Ali et al., 2021

MEAWW (2020). Researchers propose turning PPE waste into liquid fuel to curb plastic pollution amid pandemic and save nature. https://meaww.com/researchersproposal-ppe-waste-liquid-fuel-reduce-plastic-pollutionsave-nature-pandemic-covid-19 (November 26, 2020).

Shammi M, Tareq SM (2020) Environmental catastrophe of COVID-19: Disposal and management of PPE in Bangladesh. Glob. Soc. Welf. 8:1-4.

SLOACTIVE (2020). Plastic pollution: The impact of plastic pollution on our oceans and what we can do about it. https://sloactive.com/plastic-pollution/ (November 26, 2020).

South China Morning Post (2020). Coronavirus: China's mask-making juggernaut cranks into gear, sparking fears of over-reliance on world's workshop. https:// www.scmp.com/economy/global-economy/article /3074821/coronavirus-chinas-mask-making-juggernautcranks-gear (November 26, 2020).

Statista (2019). Global plastic waste. https:// www.statista.com/statistics/1073286/global-share-plasticconsumption-globally-by-class/ (November 26, 2020).

The Business Standard (2020). 206.2 tons of Covid-19 wastes produced in Dhaka a day: Study. https:// tbsnews.net/coronavirus-chronicle/covid-19bangladesh/206218-tonnes-covid-19-wastes-produceddhaka-day-study (November 26, 2020).

The Daily Star (2020). The rise in plastic pollution during covid-19 crisis. https://www.thedailystar.net/opinion/ news/the-rise-plastic-pollution-during-covid-19-crisis1931925 (November 26, 2020).

The Economist. Covid-19 has led to a pandemic of plastic pollution.

https://www.economist.com/international/2020/06/22/cov id-19-has-led-to-a-pandemic-of-plastic-pollution (November 26, 2020).
The Guardian (2020). More masks than jellyfish': Coronavirus waste ends up in ocean. https://www.theguardian.com/environment/2020/jun/08/ more-masks-than-jellyfish-coronavirus-waste-ends-up-inocean?CMP=share_btn_fb\&fbclid=IwAR0sdZK8692far9 Z1dsgsgGQKOtMoX5oR2jbT1kPYRhc0QKTUPd0asSIpg.

Trims Sourcing. http://www.trimssbd.com/ (November 26, 2020).

TRIPLE PUNDIT (2018). Our plastic problem: Plastics in marine life and beyond. https://www.triplepundit.com/ story/2018/our-plastic-problem-plastics-marine-life-andbeyond/11841 (November 26, 2020).

UNCTAD (2020). Growing plastic pollution in wake of COVID-19: How trade policy can help. https://unctad.org/news/growing-plastic-pollution-wakecovid-19-how-trade-policy-can-help (November 26, 2020).

UNEP (2018). Single-use plastics, a roadmap for sustainability.

https://www.unenvironment.org/resources/report/singleuse-plastics-roadmap-sustainability (November 26, 2020).

WebMD (2020). How long does the coronavirus live on surfaces? https://www.webmd.com/lung/how-long-covid19-lives-on-surfaces (November 26, 2020).

Zambrano-Monserrate MA, Ruano MA, and SanchezAlcalde L (2020). Indirect effects of COVID-19 on the environment. Sci. Total Environ. 728: 138813 (1-4).

Zheng J, Suh SW (2019). Strategies to reduce the global carbon footprint of plastics. Nat. Clim. Change 9(5): 374-78. 